\title{
Production of Succinic Acid: Effects of C:N Ratio
}

\author{
Tatiane Araujo Gonzales \\ UNICAMP - University of Campinas, DEA/FEA - School of Food Engineering, \\ 13083-862 Campinas, São Paulo, Brazil \\ E-mail: tatigonzales1@yahoo.com.br
}

\begin{abstract}
Lucielen Oliveira dos Santos
FURG - Federal University of Rio Grande, College of Chemistry and Food Engineering, 96203-900, Rio Grande, RS, Brazil

E-mail: santoslucielen@gmail.com
\end{abstract}

\begin{abstract}
Beatriz Torsani Ubeda
UNICAMP - University of Campinas, DEA/FEA - School of Food Engineering, 13083-862 Campinas, São Paulo, Brazil

E-mail: bia_ubeda@hotmail.com
\end{abstract}

Ranulfo Monte Alegre

UNICAMP - University of Campinas, DEA/FEA - School of Food Engineering, 13083-862 Campinas, São Paulo, Brazil

E-mail: ranulfo@unicamp.br
Rosana Goldbeck (Corresponding author)
UNICAMP - University of Campinas, DEA/FEA - School of Food Engineering, 13083-862 Campinas, São Paulo, Brazil

Tel: 55-193-521-4038 E-mail: goldbeck@unicamp.br

https://orcid.org/0000-0003-2953-8050 


\begin{abstract}
In this work, the effects of different carbon:nitrogen $(\mathrm{C}: \mathrm{N})$ ratios, carbon source and initial carbon concentration, in liquid medium used for submerged fermentation, on biomass growth, succinic acid production and yield of product in substrate $\left(\mathrm{Y}_{\mathrm{P} / \mathrm{S}}\right)$ were studied. It was used three carbon sources as substrate such as glucose, xylose and sucrose and the C:N ratios studied were in the range of 2.5-35. The succinic acid production was best at a $\mathrm{C}: \mathrm{N}$ ratio of 12.5:1, as much for the succinic acid production as for the yield of product in relation to the substrate $\left(\mathrm{Y}_{\mathrm{P} / \mathrm{S}}\right)$. For the biomass growth the $\mathrm{C}: \mathrm{N}$ ratios of 2.5:1, 5:1 and 10:1 had only presented significant difference with regards to the too much assays. The substrate that presents the best results was the glucose with succinic acid concentrations up to 7.5 g.L $\mathrm{L}^{-1}$.
\end{abstract}

Keywords: C:N ratio, Actinobacillus succinogenes, Succinic acid

\title{
1. Introduction
}

Succinic acid, also known as "amber acid", is a C4 linear saturated dicarboxylic acid produced as an intermediate of the tricarboxylic acid cycle and also as one of the fermentation products of anaerobic metabolism (Zeikus et al., 1999; Song \& Lee, 2006).

The acid and its derivatives have received considerable attention in the last two decades owing to their use as specialty chemicals for applications in food, pharmaceutical and cosmetic industries (Zeikus et al., 1999; Guettler et al., 1996; Vemuri et al., 2002). It is also used as surfactant, detergent extender, antifoam agent, ion chelators, and industrially used as raw material for important chemicals such as: 1,4 butanediol, N-methyl pyrrolidinone, gamma-butyrolactone, adipic acid, tetrahydrofuran, 2-pyrrolidinone, succinate salts. (Zeikus et al., 1999; Landucci et al., 1994; Glassner et al., 1995). Beyond that, succinic acid can be used in the synthesis of biodegradable polymers such as polybutyrate succinate (PBS) and polyamides (Nylon), and that increases the demand for this product. (Song \& Lee, 2006; Willke \& Vorlop, 2004; Hong et al., 2000; Sriram \& Dennis, 1999) and various green solvents (Zeikus et al., 1999; Song \& Lee, 2006; Millard et al., 1996).

Succinic acid is mainly produced by conversion of maleic anhydride to succinic acid by petrochemical-based processes, which limits the use of succinic acid for the wide range of applications. Recently, due to the environmental concerns and the concepts of sustainability, researches are directed towards the production of succinic acid by microbial fermentation (Lee et al., 2003a; Lee et al., 2003b; Mckinlay et al., 2005; Agarwal et al., 2006). It is also notable that greenhouse gas $\mathrm{CO}_{2}$ is fixed into succinic acid during the fermentation, thus providing an additional advantage to the process (Song \& Lee, 2006).

Many different microorganisms have been screened and studied for succinic acid production from various carbon sources. Among them, Anaerobiospirillum succiniciproducens (Nghiem 
et al., 1997), Actinobacillus succinogenes (Gluettler et al., 1999; Liu et al., 2008), Mannheimia succiniciproducens (Lee et al., 2002), Enterococcus flavescens (Agarwal et al., 2007), Bacteroides fragilis (Isar et al., 2006) and engineered Escherichia coli strains (Vermuri et al., 2002; Millard et al., 1996).

Bacteria A. succinogenes and M. succiniciproducens are the best candidates for succinic acid production as they produce succinic acid as a major fermentation product (Song \& Lee, 2006; Bechthold et al., 2008). Many studies have been reported in the literature about these bacteria (Liu et al., 2008; Du et al., 2007; Wan et al., 2008; Song et al., 2007).

Bacteria demand carbon, nitrogen and other nutrients for synthesis of its cellular components. It is important that bacteria keep right equilibrium between catabolism and anabolism for their metabolism to work efficiently. Catabolism provides energy and the constituents of the main building blocks of the cell, which are in turn used for anabolic reactions (Commichau et al., 2006).

Culture medium is usually important to the yield of any fermentation products, and carbon and nitrogen sources generally play a significant role because these nutrients are directly linked with cell growth and metabolite biosynthesis (Nghiem et al., 1997; Mao et al., 2005; Casas López et al., 2003; Lee et al., 1999), moreover its assimilation is coordinated and controlled by the availability of both nutrients (Doucette, et al., 2011; Commichau et al., 2006).

It is well known that the carbon to nitrogen $\mathrm{C}: \mathrm{N}$ ratio in the medium is one of the most important factors that influence the metabolite production of many fermentation processes (Rosfarizan \& Ariff, 2000; Madihah et al., 2001; Lin \& Lay, 2004). However, the effect of $\mathrm{C}: \mathrm{N}$ ratio on the performance of succinic acid fermentation is not available in the literature.

Thus being, the present work has as objective to verify which it is the best $\mathrm{C}: \mathrm{N}$ ratio on the yield of biomass and for the production of succinic acid.

\section{Material and Methods}

\subsection{Microorganisms and Culture Medium}

Actinobacillus succinogenes strain (CIP 106512) was obtained from the Institute Pasteur (Paris, France). The stock culture was maintained in Trypticase soy agar slants at $4{ }^{\circ} \mathrm{C}$. The growth medium contained the following (in g. $\mathrm{L}^{-1}$ of deionized water): yeast extract, 5.0; $\mathrm{NaHCO}_{3}, 10.0 ; \mathrm{NaH}_{2} \mathrm{PO}_{4} . \mathrm{H}_{2} \mathrm{O}, 8.5 ; \mathrm{K}_{2} \mathrm{HPO}_{4}, 15.5$. The $\mathrm{pH}$ of the medium was adjusted to 7.0 with hydrochloric acid after autoclaving. Separately autoclaved solution of carbohydrate (final concentration 10 g.L ${ }^{-1}$ ) was added aseptically to the medium after autoclaving.

\subsection{Culture Conditions}

Inoculum was prepared by transferring cells agar slant into $250 \mathrm{~mL}$ flask, containing $80 \mathrm{~mL}$ of the growth medium and incubated for $16 \mathrm{~h}$ in an orbital shaking incubator (Marconi, Mod. MA 830, Piracicaba, Brazil) at $150 \mathrm{rpm}$ and $37{ }^{\circ} \mathrm{C}$. Batch fermentations were carried out in butyl-rubber-stoppered, $60 \mathrm{~mL}$ serum vials containing $30 \mathrm{~mL}$ medium with $\mathrm{CO}_{2}$ as the gas 
phase. Media were inoculated with $5 \%(\mathrm{v} / \mathrm{v})$ of inoculum in the same medium and incubated at $37^{\circ} \mathrm{C}$ and $150 \mathrm{rpm}$ for $24 \mathrm{~h}$.

\subsection{Effect of C:N Ratio of Liquid Medium on Production of Succinic Acid}

According to the chemical composition of the medium mentioned above, ten liquid media with different $\mathrm{C}: \mathrm{N}$ ratios, range 2.5-35, were prepared for each substrate studied (glucose, sucrose and xylose). The variation of the concentrations of the carbon and nitrogen sources in the composition of each medium, in each run is shown in Table 1. The concentrations of carbon and nitrogen of the sugars and yeast extract, respectively, were determined to calculate the $\mathrm{C}: \mathrm{N}$ ratios required. The carbon content of glucose was $40 \%$ based on the chemical formula of $\mathrm{C}_{6} \mathrm{H}_{12} \mathrm{O}_{6}$, so $\mathrm{C}\left(\mathrm{g} . \mathrm{L}^{-1}\right)$ concentration equals the mass of glucose $\left(\mathrm{g} . \mathrm{L}^{-1}\right) * 40 \%$. The calculations for sucrose and xylose were done the same way. The nitrogen content of the yeast extract was $12.35 \%$. The $\mathrm{N}\left(\mathrm{g} \cdot \mathrm{L}^{-1}\right)$ concentration equals the mass of yeast extract $\left(\mathrm{g} . \mathrm{L}^{-1}\right) * 12.35 \%$. Then, the yeast extract concentration in the medium was fixed and the concentration of glucose, sucrose and xylose calculated considering the required $\mathrm{C}: \mathrm{N}$ ratio.

Table 1. Chemical composition of the liquid media with different $\mathrm{C}: \mathrm{N}$ ratios

\begin{tabular}{llllll}
\hline $\begin{array}{l}\text { Glucose and Xylose } \\
\left(\mathrm{g} . \mathrm{L}^{-1}\right)\end{array}$ & $\begin{array}{l}\text { Sucrose } \\
\left(\mathrm{g} . \mathrm{L}^{-1}\right)\end{array}$ & $\begin{array}{l}\text { Carbon } \\
\left(\mathrm{g} . \mathrm{L}^{-1}\right)\end{array}$ & $\begin{array}{l}\text { Yeast Extract } \\
\left(\mathrm{g} . \mathrm{L}^{-1}\right)\end{array}$ & $\begin{array}{l}\mathrm{N} \\
\left(\mathrm{g} . \mathrm{L}^{-1}\right)\end{array}$ & $\begin{array}{l}\mathrm{C}: \mathrm{N} \\
\text { ratio }\end{array}$ \\
\hline 3.859 & 3.667 & 1.544 & 5 & 0.618 & $2.5: 1$ \\
7.719 & 7.333 & 3.088 & 5 & 0.618 & $5: 1$ \\
10.00 & 9.500 & 4.000 & 5 & 0.618 & $6.5: 1$ \\
15.438 & 14.666 & 6.175 & 5 & 0.618 & $10: 1$ \\
19.297 & 18.332 & 7.719 & 5 & 0.618 & $12.5: 1$ \\
23.156 & 21.998 & 9.263 & 5 & 0.618 & $15: 1$ \\
30.875 & 29.331 & 12.350 & 5 & 0.618 & $20: 1$ \\
38.594 & 36.664 & 15.438 & 5 & 0.618 & $25: 1$ \\
46.313 & 43.997 & 18.525 & 5 & 0.618 & $30: 1$ \\
54.031 & 51.330 & 21.613 & 5 & 0.618 & $35: 1$ \\
\hline
\end{tabular}

\subsection{Analytical Methods}

The nitrogen content of the yeast extract was determinate by Hach ${ }^{\circledR}$ kit. Cell growth was measured as optical density at $660 \mathrm{~nm}$ (OD660) with an ultraviolet (UV) spectrophotometer (HACH, Mod. DR/4000U, Colorado, USA). Dry cell weight was determined using precalculated standard curves by substituting OD660 values.

The residual glucose and sucrose concentrations were measured in the cell-free supernatant by a glucose oxidase-peroxidase method using an enzymatic kit (Laborclin, Pinhais, Brazil). The residual xylose concentration was analyzed by colorimetric method of Somogyi-Nelson (Somogyi, 1952; Nelson, 1944). 
Succinic acid concentration was quantified by the enzymatic kit Boehringer Mannheim/R-Biopharm and high performance liquid chromatography equipped with a reverse phase column $\mathrm{C} 18(150 \times 4.6 \mathrm{~mm}$ ID, $3 \mu \mathrm{m})$ with temperature of $50{ }^{\circ} \mathrm{C}$ using $0.01 \mathrm{M}$ $\mathrm{KH}_{2} \mathrm{PO}_{4}$ ( $\mathrm{pH} 2.59$, adjusted with phosphoric acid) as mobile phase with flow rate of 0.5 $\mathrm{ml} . \mathrm{mim}^{-1}$.

\subsection{Determination of Kinetics Parameters}

The cell growth yield on sugar $\left(\mathrm{Y}_{\mathrm{X} / \mathrm{S}}\right)$, succinic acid yield on glucose $\left(\mathrm{Y}_{\mathrm{P} / \mathrm{S}}\right)$, succinic acid yield on biomass $\left(\mathrm{Y}_{\mathrm{P} / \mathrm{X}}\right)$ and Succinic acid productivity were calculated using the following equations:

$$
\begin{gathered}
Y_{X / S} \frac{X_{f}-X_{i}}{S_{i}-S_{f}} \\
Y_{P / S} \frac{S A_{f}}{S_{i}-S_{f}} \\
Y_{P / X} \frac{S A_{f}}{X_{f}-X_{i}} \\
P=\frac{S A_{f}}{t_{f}}
\end{gathered}
$$

where: $X_{f}$ is final biomass concentration $\left(g . L^{-1}\right) ; X_{i}$ is initial biomass concentration $\left(g . L^{-1}\right)$; $S_{f}$ is final substrate concentration $\left(\mathrm{g} . \mathrm{L}^{-1}\right) ; \mathrm{S}_{\mathrm{i}}$ is initial substrate concentration $\left(\mathrm{g} . \mathrm{L}^{-1}\right)$; $\mathrm{SA}_{\mathrm{f}}$ is the final succinic acid concentration $\left(\mathrm{g} . \mathrm{L}^{-1}\right)$ and $\mathrm{t}_{\mathrm{f}}$ is the fermentation time $(\mathrm{h})$.

\subsection{Statistical Analysis}

Statistica version 5.5 (Statsoft, USA) software was used to calculate the analysis of variance (ANOVA). Tukey test was used to determinate differences between samples using a significative level of $5 \%$.

\section{Results and Discussion}

According Mao et al. (2005) and Casas López et al. (2003) the carbohydrates are important carbon and energy sources for the cell culture and their nature and quantity in the culture medium influence the cell growth.

One of the most important factors in optimization of culture media on biomass production is the C:N ratio (Lin \& Lay, 2004).

To date the succinic acid productions with different $\mathrm{C}: \mathrm{N}$ ratios were not reported. Thus to investigate the effects of $\mathrm{C}: \mathrm{N}$ ratio on succinic acid production by Actinobacillus succinogenes, in all experiments the quantity of nitrogen in the medium was held constant and the initial $\mathrm{C}$ content were varied using glucose, xylose or sucrose. Nitrogen was the limiting nutrient in all cases.

The Figure 1 shows the maximal biomass productions obtained in the each experiment of the 
different carbon sources evaluated.

The maximum biomass production from xylose occurred in $48 \mathrm{~h}$ of fermentation, sucrose in $36 \mathrm{~h}$ and glucose in $24 \mathrm{~h}$. For all sugars, it was observed that the higher the $\mathrm{C}: \mathrm{N}$ ratio greater biomass is achieved, indicating growth limitation at low value of $\mathrm{C}: \mathrm{N}$ ratio.

The most of the microorganisms has inhibition on cell grown in concentrations of the carbon source up to $20 \mathrm{~g} . \mathrm{L}^{-1}$. It verified, in the Table 1, that the carbon source concentrations used, from C:N 15:1 ratio always are higher to $20 \mathrm{~g} . \mathrm{L}^{-1}$, indicating that the bacteria Actinobacillus succinogenes presents no inhibition of the growth in concentrations up to 55.0 g. $\mathrm{L}^{-1}$, mainly when xylose is used as carbon source.

The maximum succinic acid production in liquid medium with different $\mathrm{C}: \mathrm{N}$ ratios using the three carbon sources is shown in the Figure 2. The maximal succinic acid productions were 7.50, 4.04 and 3.93 g. $\mathrm{L}^{-1}$ in glucose, sucrose and xylose medium, respectively and their corresponding productivity were $0.315,0.112$ and $0.08 \mathrm{~g} \cdot \mathrm{L}^{-1} \cdot \mathrm{h}^{-1}$.

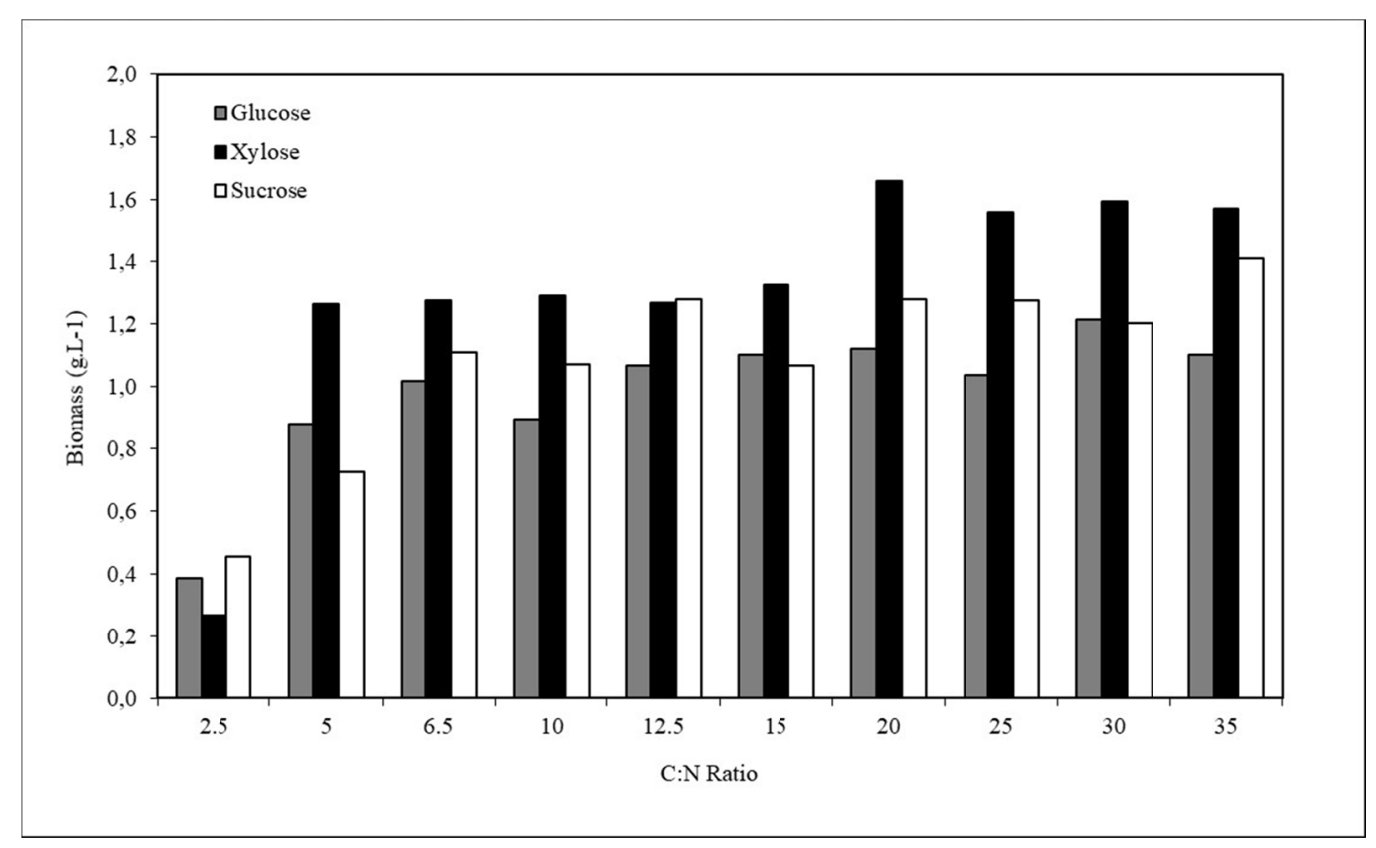

Figure 1. Effect of $\mathrm{C}: \mathrm{N}$ ratio on biomass production of Actinobacillus succinogenes for different carbon source (xylose), (sucrose) and (glucose)

This lower acid production, in medium with xylose or sucrose, probably is due the kind of the sugars used. The sucrose is a disaccharide that used to be hydrolyzed in its monosaccharides before fermented, being necessary some metabolic effort, while the xylose is metabolized by other pathway.

Besides, Van der Weff et al. (1997) in their studies showed that the use of the more-reduced sugars resulted in the formation of higher amounts of succinate, approving the results 
obtained in this work, since it were obtained betters results in the fermentation with glucose as substrate than with xylose and sucrose. Furthermore, the sucrose is no reduce sugar. Some reports have showed that the initial sugar concentration could influence cell growth and metabolites production (Lee et al., 1999; Urbance et al., 2004; Liu et al., 2008).

In the fermentations, using glucose as carbon source, the best $\mathrm{C}: \mathrm{N}$ ratios were between of 12.5:1 and 25:1 and the highest or lowest $\mathrm{C}: \mathrm{N}$ ratio resulted in relatively lower succinic acid production (Figure 2). The highest succinic acid production was obtained at $\mathrm{C}: \mathrm{N}$ ratio of 12.5:1. However, this was not statistically different $(\mathrm{p}>0.05)$ of the $\mathrm{C}: \mathrm{N}$ ratios of $15: 1,20: 1$ and 25:1 (Figure 2).

The results indicate that a high initial glucose concentration (40-55 g. $\left.\mathrm{L}^{-1}\right)$ was unfavorable to formation of succinic acid. Liu et al. (2008) studied the initial glucose concentration in fermentation by $A$. succinogenes CGMCC1593. The authors observed that concentrations up 65 g. $\mathrm{L}^{-1}$ inhibited the succinic acid production and biomass formation. Furthermore, in this study the authors used a different strain.

In the experiments using xylose as carbon source, the lower succinic acid concentrations were obtained in low $\mathrm{C}$ : $\mathrm{N}$ ratio (2.5-5.0). The others experiments showed concentrations around $3.8 \mathrm{~g} . \mathrm{L}^{-1}$. However, this was not statistically different $(\mathrm{p}<0.05)$ from that of the $\mathrm{C}: \mathrm{N}$ ratios of 15:1, 20:1 and 25:1 (Figure 2).

With respect to the experiments that the carbon source was sucrose, all experiments showed little change in the maximum concentrations of succinic acid. The experiments which the C:N ratio ranged from 6.0 to 12.5 showed no significant difference $(p<0.05)$ between them, but were different from all others.

The results, in the Figure 2, showed that the tolerable limit of $\mathrm{C}: \mathrm{N}$ ratio for the succinic acid production was not too narrow in view of the best succinic acid production was at $\mathrm{C}: \mathrm{N}$ ratio $12.5: 1$, although was not statistically different of the $C: N$ ratios 15:1, 20:1, 25:1. Reduced succinic acid production at low $\mathrm{C}: \mathrm{N}$ ratio may be due the little available carbon source, and in high $\mathrm{C}: \mathrm{N}$ ratios there is nitrogen deficiency which limits biomass growth and in consequence the production of succinic acid (Bevilaqua et al., 2015; Madihah et al., 2001). According to Liu et al. (2008), the nitrogen source is responsible by the best cellular growth for $A$. succinogenes.

Making up a general analysis of all the trials, we can say that the best $\mathrm{C}: \mathrm{N}$ ratio for the production of succinic acid is in the range of 10.0-20.0 and the best carbon source was glucose. 


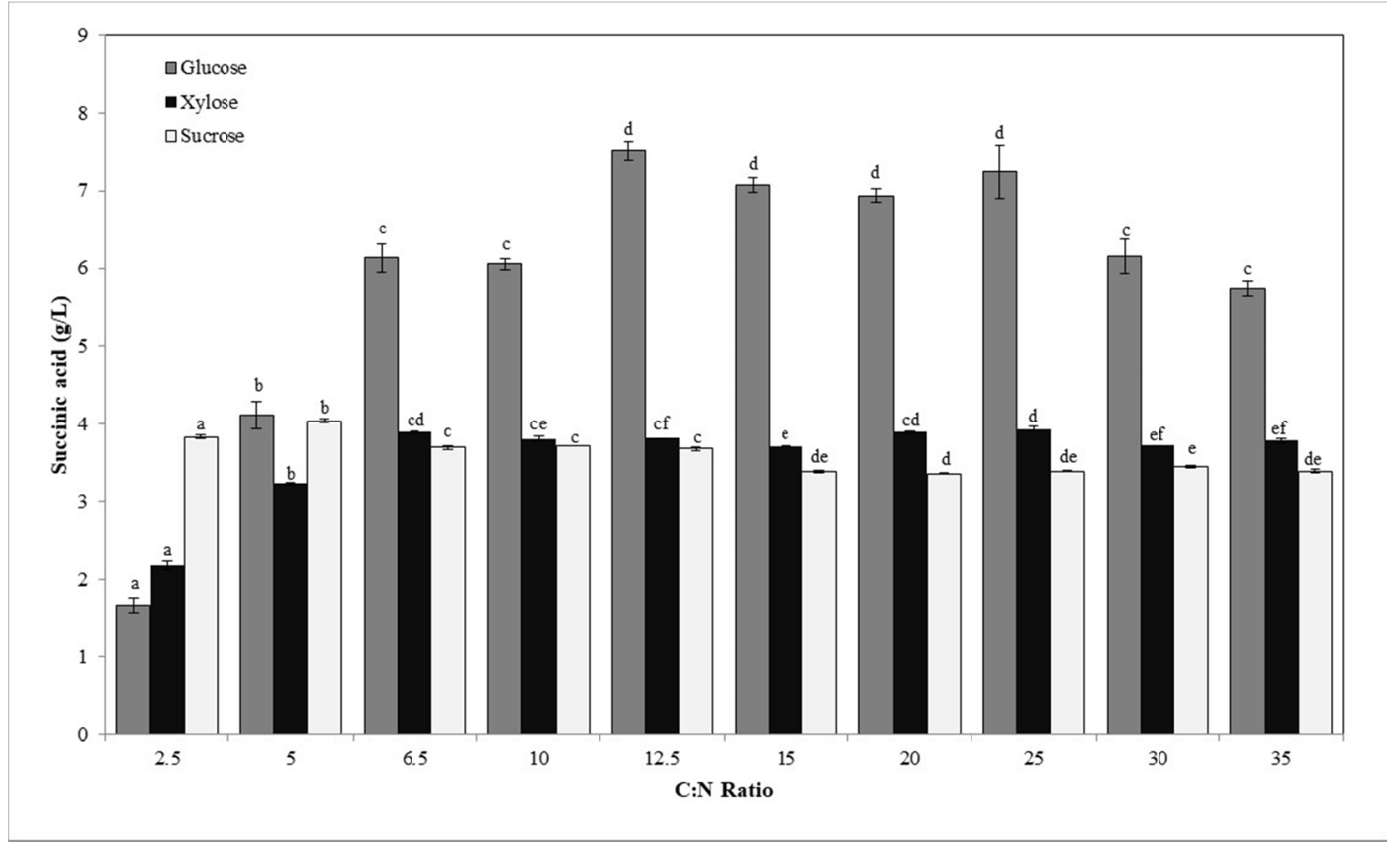

Figure 2. Succinic acid production on medium with different $\mathrm{C}: \mathrm{N}$ ratios. * Columns with different letters represent significant difference at $\mathrm{P}<0.05$ (one-way ANOVA. Tukey_HSD)

Table 2 summarizes the yields $\left(\mathrm{Y}_{\mathrm{P} / \mathrm{S}}, \mathrm{Y}_{\mathrm{X} / \mathrm{S}}\right.$ and $\left.\mathrm{Y}_{\mathrm{P} / \mathrm{X}}\right)$ and productivities obtained for each carbon source evaluated.

The cell yield on sugar decreased with an increase of $\mathrm{C}: \mathrm{N}$ ratios, probably because initial glucose concentration increase too with the increase of the $\mathrm{C}: \mathrm{N}$ ratios. It was reported that the osmotic pressure caused by a high glucose concentration might be detrimental to the metabolite biosynthesis although the cell growth was not inhibited (Mao et al., 2005).

The best yield of product in relation to the substrate $\left(\mathrm{Y}_{\mathrm{P} / \mathrm{S}}\right)$ had been found when glucose was used as carbon source with $\mathrm{C}: \mathrm{N}$ ratios of $6.5: 1$ and 12.5:1, however there was not significant difference between them in the level of $\mathrm{p}<0.05$, being the yield values around $65 \%$.

Analyzing the Table 2, when glucose was used, high C:N ratios had presented relatively lower yield than low $\mathrm{C}: \mathrm{N}$ ratios, probability by the microorganism inhibition. When the carbon source used was sucrose the yield $Y_{\mathrm{P} / \mathrm{S}}$ decreased with the increased of the ratio $\mathrm{C}: \mathrm{N}$, indicating inhibition by substrate. Already in the experiments using xylose as carbon source most trials in low $\mathrm{C}: \mathrm{N}$ ratios showed yield around $0.4 \mathrm{~g}_{\text {product }} / \mathrm{g}_{\text {substrate }}$.

It is apparent that the highest succinic acid production and productivity were obtained in glucose medium, whereas the cell growth in xylose medium was preferred. Different carbon sources might have different effects of catabolic repression on the cellular metabolism (Mao et al., 2005).

The results obtained from this study should help design a better strategy for the production of succinic acid by $A$. succinogenes. 
Table 2. Yields $\left(\mathrm{Y}_{\mathrm{P} / \mathrm{S}}, \mathrm{Y}_{\mathrm{X} / \mathrm{S}}\right.$ and $\left.\mathrm{Y}_{\mathrm{P} / \mathrm{X}}\right)$ and productivities obtained for each carbon source evaluated

\begin{tabular}{|c|c|c|c|c|c|c|c|c|c|c|c|c|}
\hline \multicolumn{13}{|l|}{ Parame } \\
\hline \multirow[t]{2}{*}{$\mathrm{C}: \mathrm{N}$} & \multicolumn{3}{|c|}{$\begin{array}{l}\text { Cell growth yield } \\
\text { on sugar }\left(\mathrm{Y}_{\mathrm{X} / \mathrm{S}}\right) \\
\left(\mathrm{g}_{\text {cell }} / \mathrm{g}_{\text {sugar }}\right)\end{array}$} & \multicolumn{3}{|c|}{$\begin{array}{l}\text { Succinic acid yield } \\
\text { on glucose }\left(\mathrm{Y}_{\mathrm{P} / \mathrm{S}}\right) \\
\left(\mathrm{g}_{\mathrm{SA}} / \mathrm{g}_{\text {sugar }}\right)\end{array}$} & \multicolumn{3}{|c|}{$\begin{array}{l}\text { Succinic acid } \\
\text { yield on biomass } \\
\left(\mathrm{Y}_{\mathrm{P} / \mathrm{X}}\right) \\
\left(\mathrm{g}_{\mathrm{SA}} / \mathrm{g}_{\text {biomass }}\right)\end{array}$} & \multicolumn{2}{|c|}{$\begin{array}{l}\text { Succinic } \\
\text { productivity } \\
\left(\mathrm{g} \cdot \mathrm{L}^{-1} \cdot \mathrm{h}^{-1}\right)\end{array}$} & \multirow{2}{*}{$\begin{array}{l}\text { acid } \\
\text { Suc }\end{array}$} \\
\hline & Glu & Xyl & Suc & Glu & Xyl & Suc & Glu & Xyl & Suc & Glu & Xyl & \\
\hline $2.5: 1$ & 0.11 & 0.05 & 0.07 & 0.52 & 0.02 & 1.06 & 4.7 & 12.3 & 14.7 & 0.07 & 0.05 & 0.11 \\
\hline $5: 1$ & 0.11 & 0.16 & 0.07 & 0.54 & & 0.55 & 4.9 & 2.8 & 7.7 & 0.17 & 0.07 & 0.11 \\
\hline $6.5: 1$ & 0.10 & 0.12 & 0.10 & 0.6 & 0.39 & 0.38 & 6.1 & 3.3 & 4.0 & 0.26 & 0.08 & 0.10 \\
\hline 10:1 & 0.08 & 0.14 & 0.08 & 0.5 & 0.46 & 0.35 & 6.9 & 3.2 & 4.2 & 0.25 & 0.08 & 0.10 \\
\hline $12.5: 1$ & 0.09 & 0.12 & 0.08 & 0.64 & 0.39 & 0.28 & 7.2 & 3.3 & 3.4 & 0.32 & 0.08 & 0.10 \\
\hline $15: 1$ & 0.09 & 0.14 & 0.07 & 0.59 & 0.43 & 0.26 & 6.6 & 3.0 & 3.8 & 0.29 & 0.08 & 0.09 \\
\hline 20:1 & 0.08 & 0.22 & 0.07 & 0.47 & 0.58 & 0.21 & 6.3 & 2.5 & 3.1 & 0.29 & 0.08 & 0.09 \\
\hline $25: 1$ & 0.06 & 0.14 & 0.05 & 0.40 & 0.37 & 0.15 & 7.1 & 2.7 & 3.0 & 0.30 & 0.08 & 0.09 \\
\hline 30:1 & 0.09 & 0.23 & 0.06 & 0.52 & 0.60 & 0.21 & 5.1 & 2.5 & 3.3 & 0.26 & 0.08 & 0.10 \\
\hline $35: 1$ & 0.07 & 0.11 & 0.06 & 0.37 & 0.29 & 0.16 & 5.2 & 2.5 & 2.7 & 0.24 & 0.08 & 0.09 \\
\hline
\end{tabular}

\section{Conclusion}

The effects of carbon:nitrogen ratios on succinic acid production by submerged cultivation of Actinobacillus succinogenes were investigated. According to the results, the variation in the $\mathrm{C}: \mathrm{N}$ ratio on the biosynthesis of succinic acid showed that a $\mathrm{C}: \mathrm{N}$ ratio $12.5: 1$ is most suitable for maximum production of succinic acid in the three carbon source studied.

\section{Acknowledgments}

The authors acknowledge to the CNPq (Conselho Nacional de Desenvolvimento Científico e Tecnológico)/Brazil for the financial support. This study was financed in part by CAPES finance code 001.

\section{References}

Agarwal, L., Isar J, Meghwanshi, G. K., \& Saxena, R. K. (2006). A cost effective fermentative production of succinic acid from cane molasses and corn steep liquor by Escherichia coli. Journal Applied Microbiology, 100, 1348-1354. https://doi.org/10.1111/j.1365-2672.2006.02894.x

Agarwal, L., Isar, J., Meghwanshi, G. K., \& Saxena, R. K. (2007). Influence of environmental and nutricional factors on succinic acid production and enzymes of reverse tricarboxylic acid cycle from Enterococcus flavescens. Enzyme Microbiology Technology, 40, 629-636. https://doi.org/10.1016/j.enzmictec.2006.05.019

Bechthold, I., Bretz, K., Kabasci, S., Kopitzky, R., \& Springer, A. (2008). Succinic acid: A 
new platform chemical for biobased polymers from renewable resources. Chemical Engineering \& Technology, 31(5), 647-654. https://doi.org/10.1002/ceat.200800063

Bevilaqua, D. B., Montipó, S., Pedroso, G. B., \& Martins, A. F. (2015). Sustainable succinic acid production from rice husks. Sustainable Chemistry and Pharmacy, 1, 9-13. https://doi.org/10.1016/j.scp.2015.09.001

Casas López, J. L., Sánchez Pérez, J. Á., Fernández Sevilla, J. M., Acién Fernández, F. G., Molina Grima, E., \& Chisti, Y. (2003). Production of lovastatin by Aspergillus terreus: effects of the $\mathrm{C}: \mathrm{N}$ ratio and the principal nutrients on growth and metabolite production. Enzyme Microbiology Technology, 33, 270-277. https://doi.org/10.1016/S0141-0229(03)00130-3

Commichau, F. M., Forchhammer, K., \& Stülke, J. (2006). Regulatory links between carbon and nitrogen metabolism. Current Opinion in Microbiology, 9(2), 167-172. https://doi.org/ 10.1016/j.mib.2006.01.001

Doucette et al. (2011). $\alpha$-ketoglutarate coordinates carbon and nitrogen utillization via enzyme I inhibition. Nature Chemical Biology, 7, 12, 894-901. https://doi.org/10.1038/nchembio.685

Du, S., Lin, S. K. C., Koutinas, A., Wang, R., \& Webb, C. (2007). Succinic acid production from wheat using a biorefining strategy. Applied Microbiology Biotechnology, 76, 1263-1270. https://doi.org/10.1007/s00253-007-1113-7

Glassner, D. A., Elankovan, P., Beacom, D. R., \& Berglund, K. A. (1995). Purification Process for succinic acid produced by fermentation. Applied Biochemistry and Biotechnology, 51(52), 73-82. https://doi.org/10.1007/BF02933412

Gluettler, M. V., Rumler, D., \& Jain, M. K. (1999). Actinobacillus succinogenes sp. nov., a novel succinic acid producing strain from the bovine rumen. International Journal of Systematic Bacteriology, 49, 207-216. https://doi.org/10.1099/00207713-49-1-207

Guettler, M. V., Jain, M. K., \& Soni, B. K. (1996). Process for making succinic acid, microorganisms for use in the process and methods of obtaining the microorganisms. US Patent 5,504,004.

Hong, Y. K., Hong, W. H., \& Chang, H. N. (2000). Selective extraction of succinic acid from binary mixture of succinic acid and acetic acid. Biotechnology Letter, 22, 871-874. https://doi.org/10.1023/A:1005627816323

Isar, J., Agarwal, L., Saran, S., \& Saxena, R. K. (2006). Succinic acid production from Bacteroides fragilis: Process optimization and scale up in a bioreactor. Anaerobe, 12(5-6), 231-237. https://doi.org/10.1016/j.anaerobe.2006.07.001

Landucci, R., Goodman, B., \& Wyman, C. (1994). Methodology for evaluating the economics of biologically producing chemicals and materials from alternative feedstocks. Applied Biochemistry Biotechnology, 45, 677-696. https://doi.org/10.1007/BF02941840

Lee, P. C., Lee, W. G., Lee, S. Y., \& Chang, H. N. (1999). Effects of medium components on the growth of Anaerobiospirillum succiniciproducens and succinic acid production. Process 
Biochemistry, 35, 49-55. https://doi.org/10.1016/S0032-9592(99)00031-X

Lee, P. C., Lee, W. G., Hong, S. H., \& Chang, H. N. (2002). Isolation and characterization of a new succinic acid-producing bacterium, Mannheimia succiniciproducens MBEL55E, from bovine rumen. Applied Microbiology Biotechnology, 58, 663-668. https://doi.org/10.1007/ s00253-002-0935-6

Lee, P. C., Lee, W. G., Hong, S. H., Chang, H. N., \& Park, S. C. (2003a). Biological conversion of wood hydrolysate to succinic acid by Anaerobiospirillum succiniciproducens. Biotechnology Letter, 25, 111-114. https://doi.org/10.1023/A:1021907116361

Lee, P. C., Lee, S. Y., Hong, S. H., \& Chang, H. N. (2003b). Batch and continuous cultures of Mannheimia succiniciproducens MBEL55E for the production of succinic acid from whey and corn steep liquor. Bioprocess Biosystem Engineering, 26, 63-67. https://doi.org/10.1007/ s00449-003-0341-1

Lin, C. Y., \& Lay, C. H. (2004). Carbon/nitrogen effect on fermentative hydrogen production by mixed microflora. International Journal Hydrogen Energy, 29, 41-45. https://doi.org/ 10.1016/S0360-3199(03)00083-1

Liu, Y-P., Zheng, P., Sun, Z-H., Ni, Y., Dong, J-J., \& Zhu, L-L. (2008). Economical succinic acid production from cane molasses by Actinobacillus succinogenes. Bioresource Technology, 99, 1736-1742. https://doi.org/10.1016/j.biortech.2007.03.044

Madihah, M. S., Ariff, A. B., Sahaid, K. M., Suraini, A. A., \& Karim, M. I. A. (2001). Direct fermentation of gelatinized sago starch to acetone-butanol-ethanol by Clostridium acetobutylicum. World Journal of Microbiology Biotechnology, 17, 567-576. https://doi.org/ 10.1023/A:1012351112351

Mao, X. B., Eksriwong, T., Chauvatcharin, S., \& Zhong, J. J. (2005). Optimization of carbon source and carbon/nitrogen ratio for cordycepin production by submerged cultivation of medicinal mushroom Cordyceps militaris. Process Biochemistry, 40, 1667-1672. https://doi.org/10.1016/j.procbio.2004.06.046

McKinlay, J. B., Zeikus, J. G., \& Vieille, C. (2005). Insights into Actinobacillus succinogenes fermentative metabolism in a chemically defined growth medium. Applied Environmental Microbiology, 71(11), 6651-6656. https://doi.org/10.1128/AEM.71.11.6651-6656.2005

Millard, C. S., Chao, Y. P., Liao, J. C., \& Donnelly, M. I. (1996). Enhanced production of succinic acid by overexpression of phosphoenolpyruvate carboxylase in Escherichia coli. Applied Microbiology Biotechnology, 62, 1808-1810.

Nelson, N. (1944). A photometric adaptation of the Somogyi method for the determination of glucose. Journal of Biological Chemistry, 153, 375.

Nghiem, N. P., Davison, B. E. S., \& Richardson, G. R. (1997). Production of succinic acid by Anaerobiospirillum succiniciproducens. Applied Biochemistry and Biotechnology, 63/65, 565-576. https://doi.org/10.1007/BF02920454 
Rosfarizan, M., \& Ariff, A. B. (2000). Kinetics of Kojic acid fermentation by Aspergillus flavus using different types and concentrations of carbon and nitrogen sources. Journal Industrial Microbiology Biotechnology, 25, 20-24. https://doi.org/10.1038/sj.jim.7000017

Somogyi, M. (1952). Notes on sugar determination. Journal of Biological Chemistry, 195, 19-23.

Song, H., \& Lee, S. Y. (2006). Production of succinic acid by bacterial fermentation. Enzyme Microbiology Technology, 39, 352-361. https://doi.org/10.1016/j.enzmictec.2005.11.043

Song, H., Lee, J. W., Choi, S., You, J. K., Hong, W. H., \& Lee, S. Y. (2007). Effects of Dissolved $\mathrm{CO}_{2}$ levels on the growth of Mannheimia succiniciproducens and succinic acid production. Biotechnology Bioengineering, 98(6), 1296-1304. https://doi.org/10.1002/ bit. 21530

Sriram, V., \& Dennis, J. M. (1999). Catalytic upgrading of fermentation derived organic acids. Biotechnology Progress, 15, 845-854. https://doi.org/10.1021/bp9900965

Urbance, S. E., Pometto, A. L., Dispirito, A. A., \& Denli, Y. (2004). Evaluation of succinic acid continuous and repeat-batch biofilm fermentation by Actinobacillus succinogenes using plastic composite support bioreactors. Applied Microbiology Biotechnology, 65, 664-670. https://doi.org/10.1007/s00253-004-1634-2

Van der Weff, M. J., Guettler, M. V., Jain, M. K., \& Zeikus, J. G. (1997). Environmental and physiological factors affecting the succinate product ratio during carbohydrate fermentation by Actinobacillus succinogenes sp. 130Z. Archives Microbiology, 167, 332-342. https://doi.org/10.1007/s002030050452

Vemuri, G. N., Eiteman, M. A., \& Altman, E. (2002). Effects of growth mode and pyruvate carboxylase on succinic acid production by metabolically engineered strains of Escherichia coli. Applied Environmental Microbiology, 1715-1727. https://doi.org/10.1128/AEM.68.4. 1715-1727.2002

Wan, C., Li, Y., Shahbazi, A., \& Xiu, S. (2008). Succinic acid production from cheese whey using Actinobacillus succinogenes 130Z. Applied Biochemistry Biotechnology, 145, 111-119. https://doi.org/10.1007/s12010-007-8031-0

Willke, T., \& Vorlop, K. D. (2004). Industrial bioconversion of renewable resources as an alternative to conventional chemistry. Applied Microbiology Biotechnology, 66, 131-142. https://doi.org/10.1007/s00253-004-1733-0

Zeikus, J. G., Jain, M. K., \& Elankovan, P. (1999). Biotechnology of succinic acid production and markets for derived industrial products. Applied Microbiology Biotechnology, 51, 545-552. https://doi.org/10.1007/s002530051431 


\section{Macrothink

\section{Copyright Disclaimer}

Copyright reserved by the author(s).

This article is an open-access article distributed under the terms and conditions of the Creative Commons Attribution license (http://creativecommons.org/licenses/by/3.0/). 